\title{
Analisis Metode Delineasi Bidang Tanah pada Citra Resolusi Tinggi dalam Pembuatan Kadaster Lengkap
}

\author{
Arinda Kusuma Wardani, Agung Budi Cahyono, dan Dwi Budi Martono \\ Jurusan Teknik Geomatika, Fakultas Teknik Sipil dan Perencanaan, Institut Teknologi Sepuluh \\ Nopember (ITS) \\ Jl. Arief Rahman Hakim, Surabaya 60111 Indonesia \\ e-mail: agungbc@geodesy.its.ac.id,dwibudimartono@gmail.com
}

\begin{abstract}
Abstrak-Delineasi bidang tanah dilakukan dengan cara mengidentifikasi bidang-bidang tanah dengan menggunakan peta foto dan menarik garis ukur untuk batas bidang tanah yang jelas dan memenuhi syarat. Dalam penarikan batas, ada 2 metode yang dapat dijadikan sebagai acuan, yaitu delineasi metode general boundary (penarikan batas dari kenampakan yang terlihat) dan delineasi metode fixed boundary (penarikan batas dari hasil pengukuran di lapangan). Delineasi dengan metode general boundary dapat dijadikan sebagai alat dalam percepatan pembangunan basis data bidang tanah yang lengkap, cepat dan lebih murah. Berdasarkan analisis yang telah dilakukan dari beberapa delineasi metode general boundary, hasil ketelitian yang paling mendekati toleransi adalah delineasi metode general boundary pada skala perbesaran 1:1000 dengan penarikan batas sisi tengah dari kenapampakan yang terlihat (hasil dilihat dari jumlah sampel yang paling banyak diterima berdasarkan standarisasi yang telah ditetapkan). Analisis juga dilakukan dengan menggunakan uji hipotesis selisih nilai rata-rata berpasangan (uji paired t-test) untuk luas bidang sawah didapatkan hasil 0,186 ( $t_{\text {hitung }}<1,833$ ) dan luas bidang pemukiman $-1,742$ ( $t_{\text {hitung }}<-1,833$ ). Sedangkan untuk pergeseran posisi atau uji $t$ jarak didapatkan hasil koordinat $x=5,374$ (thitung $>1,699$ ) dan koordinat $y=5,469$ (thitung $>1,699$ ) ; serta koordinat $x=8,504$ ( $t_{\text {hitung }}>1,699$ ) dan koordinat $y=9,015$ ( $\left.t_{\text {hitung }}>1,699\right)$ untuk bidang pemukiman. Hasil penelitian menunjukkan bahwa metode general boundary yang dilakukan pada citra resolusi tinggi Quickbird tahun 2007 secara keseluruhan memenuhi toleransi apabila akan digunakan dalam memenuhi kebutuhan geometrik bentuk dan luas. Akan tetapi apabila untuk memenuhi kebutuhan geometrik posisi, cara ini tidak bisa diterima.
\end{abstract}

Kata Kunci-Delineasi, Fixed Boundary, General Boundary, Kadaster Lengkap

\section{PENDAHULUAN}

$\mathrm{B}$ ADAN Pertanahan Nasional merupakan Lembaga Pemerintah Non Kementerian yang berada di bawah dan bertanggungjawab kepada Presiden. BPN mempunyai tugas melaksanakan tugas pemerintahan di bidang pertanahan sesuai dengan ketentuan peraturan perundang-undangan. Untuk menyelenggarakan tugas dan fungsi BPN di daerah dibentuk Kantor Wilayah BPN di provinsi dan Kantor Pertanahan di kabupaten/kota [1]. Saat ini Kantor Pertanahan Kabupaten Gresik membangun basis data berbasis bidang tanah per desa yang disebut dengan kadaster lengkap (KAKAP) dimana data dari setiap bidang tanah diperoleh dari hasil pengukuran dan delineasi untuk bidang yang belum diukur. Tahapan dalam pembangunan KAKAP antara lain: 1) penyediaan peta dasar skala besar untuk tampilan peta dari udara dengan skala 1:1000; 2) Graphical Index Mapping (GIM) seluruh bidang tanah yang terdaftar ke dalam peta hasil koreksi; 3) delineasi seluruh bidang tanah yang belum terdaftar; 4) validasi buku tanah, surat ukur tekstual, surat ukur spasial, dan peta pendaftaran; 5) pembuatan zonasi berdasarkan batas bidang KAKAP (peta zona nilai tanah dan peta zonasi tata ruang);6) updating nilai tanah pada zona-zona baru.

Delineasi bidang tanah merupakan salah satu dari komponen dalam pembangunan kadaster lengkap. Delineasi bidang tanah dilakukan dengan cara mengidentifikasi bidangbidang tanah dengan menggunakan peta foto dan menarik garis ukur untuk batas bidang tanah yang jelas dan memenuhi syarat. Ada dua jenis kategori batas yang dapat dijadikan sebagai acuan dalam metode delineasi, antara lain adalah fixed boundaries dan general boundaries. Fixed boundaris adalah garis yang telah ditetapkan oleh yang berwenang melalui survei formal dan dinyatakan secara matematis oleh hubungan dan jarak, atau dengan koordinat. Sedangkan general boundaries adalah garis yang terlihat ada dalam kenyataan tetapi belum ditetapkan oleh pihak yang berwenang, biasanya batas tersebut berupa kenampakan fisik, baik alami atau buatan manusia seperti pagar, parit, atau jalan [2].

Dengan dilakukannya penelitian tentang analisis metode delineasi luas bidang tanah pada peta citra resolusi tinggi ini maka dapat diketahui geometrik bentuk, luas, dan posisi luas bidang yang dihasilkan serta ketelitian penggunaan dari hasil delineasi yang telah dilakukan, terutama dalam mencari luasan bidang tanah sesuai dengan standarisasi ketelitian luas yang telah ditetapkan, sehingga diharapkan pekerjaan delineasi luas bidang tanah ini dapat menjadi salah satu faktor yang mendukung percepatan dalam pembangunan KAKAP.

\section{METODOLOGI PENELITIAN}

\section{A. Lokasi Penelitian}

Lokasi yang digunakan untuk penelitian adalah Desa Wotan, Kecamatan Panceng, Kabupaten Gresik. Secara geografis wilayah Desa Wotan, Kecamatan Panceng, Kabupaten Gresik terletak antara $112^{\circ}-113^{\circ}$ BT dan $7^{\circ}-8^{\circ} \mathrm{LS}$. 


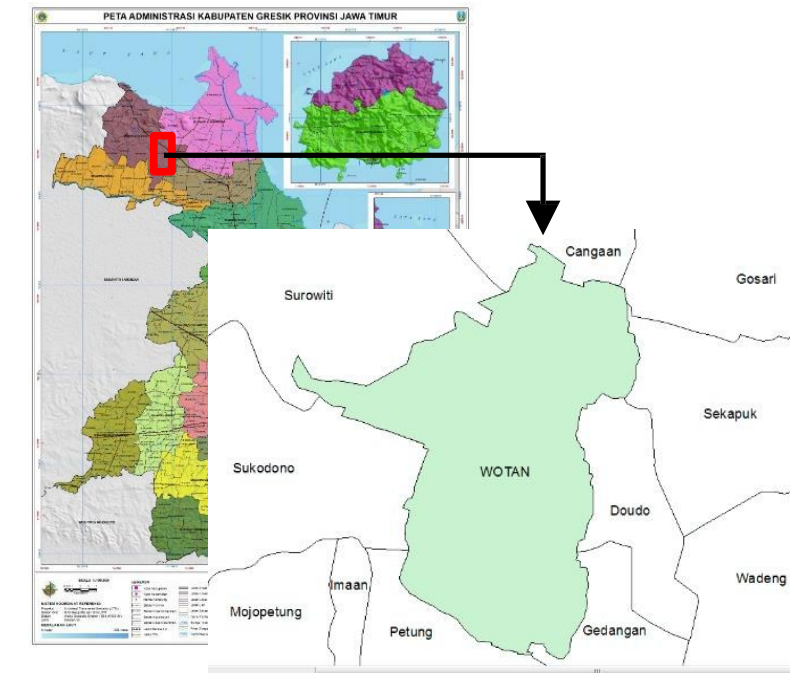

Gambar 1. Lokasi Penelitian

\section{B. Data yang Digunakan}

Penelitian ini menggunakan data antara lain:

a. Citra satelit resolusi tinggi Quickbird tahun 2007 yang telah terkoreksi dari Kantor Pertanahan Kabupaten Gresik untuk wilayah Desa Wotan, Kecamatan Panceng, Kabupaten Gresik.

b. Peta Pendaftaran Tanah skala 1:15000 Desa Wotan, Kecamatan Panceng, Kabupaten Gresik.

\section{Delineasi Bidang Tanah}

Delineasi bidang tanah dilakukan pada peta Pendaftaran Tanah untuk bidang tanah yang sudah terdaftar (fixed boundary). Delineasi juga dilakukan pada citra yang telah terkoreksi untuk bidang tanah yang sudah terdaftar sesuai dengan interpretasi (general boundary). Dalam melakukan delineasi batas obyek, ada beberapa faktor yang harus diperhatikan, yakni perbesaran (zooming) dan kaidah kartografi pemetaan dalam penafsiran citra. Pada penelitian ini, delineasi dilakukan pada beberapa perbesaran, antara lain perbesaran dengan skala 1:1000, 1:2500, dan 1:5000. Dan untuk penafsiran batas sesuai kaidah kartografi, dilakukan penarikan batas (delineasi) pada sisi batas luar, batas tengah, dan batas dalam dari kenampakan fisik obyek yang terlihat.

Delineasi dengan metode fixed boundary dan metode general boundary pada bidang yang telah terdaftar dilakukan untuk mengetahui bagaimana delineasi yang sesuai dan masuk toleransi ketelitian luas berdasarkan standarisasi dari BPN.

\section{HASILDAN ANALISA}

\section{A. Analisis Ketelititan RMSE yang Dihasilkan}

Citra Quickbird tahun 2007 yang diperoleh dari Kantor Pertanahan Kabupaten Gresik telah dilakukan koreksi geometrik secara orthorektifikasi dengan menggunakan 68 titik GCP (Ground Control Point) dan 40 titik ICP (Independent Check Point). Posisinya menyebar mengelilingi citra dengan cakupan wilayah se-Kabupaten Gresik.

Ketelitian dari citra satelit untuk titik GCP didapatkan RMSE sebesar 1,628 meter. Sedangkan titik ICP didapatkan hasil RMSE sebesar 1,59655 meter yang selanjutnya dilakukan perkalian pada nilai aman statistik confident level pada $90 \%=$ 1,5175 sehingga didapatkan nilai $=2,51$ meter [3].

\section{B. Analisis Delineasi Bidang Tanah Hasil Intepretasi Citra}

Dapat dilihat pada Tabel 1 untuk bidang sawah, kenampakan obyek pada skala 1:5000 masih dapat terlihat jelas oleh penafsir sehingga obyek dapat dilakukan pendelineasian. Sedangkan untuk bidang pemukiman, penafsir hanya mampu melakukan pendelineasian hingga batas skala 1:2500. Hal ini dikarenakan identifikasi kenampakan pemukiman pada skala 1:5000 kurang jelas dan terlalu kecil sehingga menyulitkan identifikasi batas bidangnya (lihat Tabel 1).

Tabel 1.

Kenampakan Citra berdasarkan Skala Perbesaran

\begin{tabular}{|c|c|c|}
\hline \multirow{2}{*}{$\begin{array}{c}\text { Skala } \\
\text { Perbesaran } \\
(\text { Zoom })\end{array}$} & \multicolumn{2}{|c|}{ Obyek Bidang Tanah } \\
\hline & Sawah & Pemukiman \\
\hline $1: 1000$ & & \\
\hline $1: 2500$ & & \\
\hline $1: 5000$ & & \\
\hline
\end{tabular}

Untuk penafsiran batas sesuai kaidah kartografi, dilakukan penarikan batas (delineasi) pada sisi batas luar, batas tengah, dan batas dalam dari kenampakan fisik obyek yang terlihat (ilustrasi gambar dapat dilihat pada Tabel 2). Dari hasil ketiga perlakuan penarikan batas tersebut ketelitian paling bagus yang dihasilkan adalah penarikan batas (delineasi) pada sisi batas tengah dari kenampakan fisik obyek.

Tabel 2.

Hasil Delineasi berdasarkan Penarikan Batas Pada Sisi Bidang Tanah

\begin{tabular}{cc}
\hline \hline Sisi Bidang Tanah & Kenampakan Bidang Tanah \\
\hline & \\
Sisi Dalam & \\
\hline
\end{tabular}




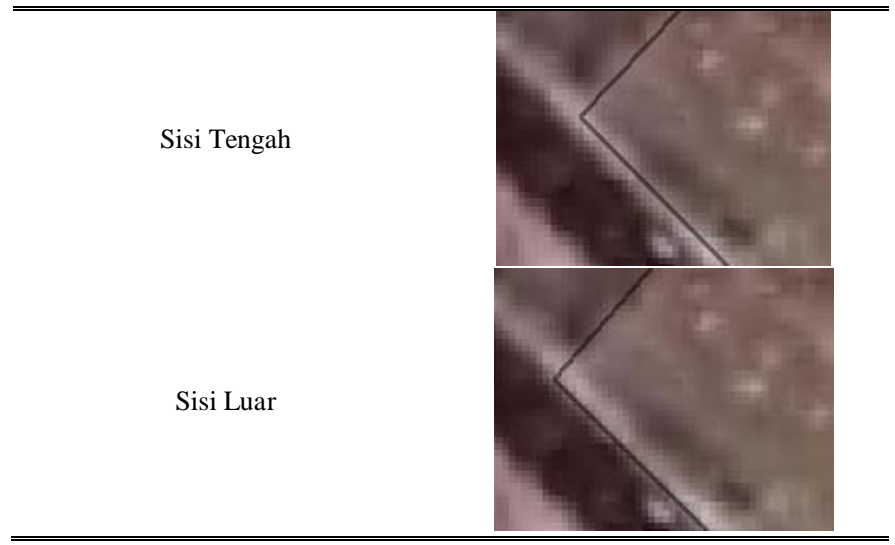

\section{Analisis Delineasi Bidang Tanah Metode Fixed Boundary} dan Metode General Boundary

\section{Analisis Perbandingan Luas}

Analisis perbandingan luas untuk mengetahui perbedaan luas yang terjadi dilakukan dengan menggunanakan uji tberpasangan (uji paired sample t-test). Uji $t$ sampel berpasangan berfungsi untuk menguji dua sampel yang berpasangan, apakah mempunyai rata-rata yang secara nyata berbeda ataukah tidak.

Uji $t$ ini menggunakan uji dua sisi dengan derajat kepercayaan $(\alpha)=10 \%$, degrees of freedom $(d f)=9, t_{\text {tabel }}=$ 1,833. Sehingga Ho diterima jika $-1,8331<\mathrm{t}_{\text {hitung }}<1,8331$ dan Ho ditolak (Ha diterima) jika $t_{\text {hitung }}<-1,8331$ atau $t_{\text {hitung }}>1,8331$. Hipotesis yang akan diuji adalah:

- Ho: Tidak terdapat perbedaan luas yang signifikan antara hasil delineasi fixed boundary dengan general boundary.

- Ha: Terdapat perbedaan luas yang signifikan antara hasil delineasi fixed boundary dengan general boundary.

Dari perhitungan diperoleh $t_{\text {hitung }}$ untuk masing-masing jenis bidang tanah dengan perlakukan delineasi yang berbeda (Tabel 3 dan Tabel 4).

Sehingga dapat disimpulkan bahwa untuk jenis bidang tanah sawah, dari 7 percobaan yang dilakukan seluruhnya tidak terdapat perbedaan luas yang signifikan antara hasil delineasi fixed boundary dengan general boundary. Sedangkan untuk jenis bidang tanah pemukiman, dari 4 percobaan yang dilakukan, 2 percobaan tidak terdapat perbedaan luas yang signifikan antara hasil delineasi fixed boundary dengan general boundary. Sedangkan 2 percobaan lainnya terjadi perbedaan luas.

Tabel 3.

T-hitung Masing-masing Pengukuran Luasan untuk Bidang Sawah

\begin{tabular}{ccccc}
\hline \hline \multicolumn{2}{c}{ Faktor Delineasi } & & & \\
\cline { 1 - 2 } $\begin{array}{c}\text { Skala } \\
\text { Perbesaran } \\
\text { (Zoom })\end{array}$ & $\begin{array}{c}\text { Penarikan } \\
\text { Batas pada } \\
\text { Sisi Bidang } \\
\text { Tanah }\end{array}$ & thitung & tabel & Keterangan \\
\hline 1:1000 & Dalam & 0,7564 & 1,8331 & Diterima \\
$1: 1000$ & Tengah & 0,1856 & 1,8331 & Diterima \\
$1: 1000$ & Luar & $-1,4447$ & 1,8331 & Diterima \\
$1: 2500$ & Dalam & 0,5159 & 1,8331 & Diterima \\
$1: 2500$ & Tengah & $-0,5079$ & 1,8331 & Diterima \\
$1: 2500$ & Luar & $-1,3388$ & 1,8331 & Diterima \\
$1: 5000$ & Tengah & $-1,0889$ & 1,8331 & Diterima \\
\hline \hline
\end{tabular}

Tabel 4.

T-hitung Masing-masing Pengukuran Luasan untuk Bidang Pemukiman

\begin{tabular}{ccccc}
\hline \hline \multicolumn{2}{c}{ Faktor Delineasi } & & & \\
\cline { 1 - 2 } $\begin{array}{c}\text { Skala } \\
\text { Perbesaran } \\
(\text { Zoom })\end{array}$ & $\begin{array}{c}\text { Penarikan } \\
\text { Batas pada } \\
\text { Sisi Bidang } \\
\text { Tanah }\end{array}$ & $\mathrm{t}_{\text {hitung }}$ & $\mathrm{t}_{\text {tabel }}$ & Keterangan \\
\hline $1: 1000$ & Dalam & 0,9386 & 1,8331 & Diterima \\
$1: 1000$ & Tengah & $-1,7421$ & 1,8331 & Diterima \\
$1: 1000$ & Luar & $-3,2747$ & 1,8331 & Ditolak \\
$1: 2500$ & Dalam & - & - & - \\
$1: 2500$ & Tengah & $-2,5081$ & 1,8331 & Ditolak \\
$1: 2500$ & Luar & - & - & - \\
$1: 5000$ & Tengah & - & - & - \\
\hline \hline
\end{tabular}

\section{Analisis Perbandingan Jarak}

Analisis perbandingan jarak yang dimaksudkan adalah analisis jarak pergeseran titik-titik pojok bidang tanah. Untuk mengetahui perbedaan jarak pergeseran titik yang terjadi, dilakukan analisis dengan menggunanakan uji t-berpasangan (uji paired sample t-test).

Uji $t$ ini menggunakan uji dua sisi dengan derajat kepercayaan $(\alpha)=10 \%$, degrees of freedom $(d f)=29$, tabel $=$ 1,6991. Sehingga Ho diterima jika $-1,6991<\mathrm{t}_{\text {hitung }}<1,6991$ dan Ho. Hipotesis yang akan diuji adalah:

- Ho: Tidak terdapat perbedaan jarak yang signifikan antara hasil delineasi fixed boundary dengan general boundary.

- Ha: Terdapat perbedaan jarak yang signifikan antara hasil delineasi fixed boundary dengan general boundary.

Dari perhitungan diperoleh $t_{\text {hitung }}$ untuk masing-masing jenis bidang tanah dengan perlakukan delineasi yang berbeda, hasil dapat dilihat pada Tabel 5 dan Tabel 6 .

Tabel 5.

T-hitung Masing-masing Pengukuran Jarak untuk Bidang Sawah

\begin{tabular}{cccccccc}
\hline \hline \multicolumn{2}{c}{ Faktor Delineasi } & \multicolumn{2}{c}{$\mathrm{t}_{\text {hitung }}$} & & \multicolumn{2}{c}{ Keterangan } \\
\cline { 1 - 2 } $\begin{array}{c}\text { Skala } \\
\begin{array}{c}\text { Perbesaran } \\
(\text { Zoom })\end{array}\end{array}$ & $\begin{array}{c}\text { Penarikan } \\
\text { Batas } \\
\text { pada Sisi } \\
\text { Bidang } \\
\text { Tanah }\end{array}$ & $\begin{array}{c}\text { Easting } \\
(\mathrm{X})\end{array}$ & $\begin{array}{c}\text { Northing } \\
(\mathrm{Y})\end{array}$ & $\mathrm{t}_{\text {tabel }}$ & & $\begin{array}{c}\text { Easting } \\
(\mathrm{X})\end{array}$ & $\begin{array}{c}\text { Northing } \\
(\mathrm{Y})\end{array}$ \\
& & & & & \\
\hline $1: 1000$ & Dalam & 5,2832 & 5,8723 & 1,6991 & Ditolak & Ditolak \\
$1: 1000$ & Tengah & 5,3743 & 5,4690 & 1,6991 & Ditolak & Ditolak \\
$1: 1000$ & Luar & 6,7681 & 5,7312 & 1,6991 & Ditolak & Ditolak \\
$1: 2500$ & Dalam & 6,5515 & 6,6061 & 1,6991 & Ditolak & Ditolak \\
$1: 2500$ & Tengah & 5,8374 & 6,0964 & 1,6991 & Ditolak & Ditolak \\
$1: 2500$ & Luar & 7,0591 & 7,3482 & 1,6991 & Ditolak & Ditolak \\
$1: 5000$ & Tengah & 7,8783 & 7,6432 & 1,6991 & Ditolak & Ditolak \\
\hline \hline
\end{tabular}

Tabel 6.

T-hitung Masing-masing Pengukuran Jarak untuk Bidang Pemukiman

\begin{tabular}{|c|c|c|c|c|c|c|}
\hline \multicolumn{2}{|c|}{ Faktor Delineasi } & \multicolumn{2}{|c|}{$t_{\text {hitung }}$} & \multirow[b]{2}{*}{$\mathrm{t}_{\text {tabel }}$} & \multicolumn{2}{|c|}{ Keterangan } \\
\hline $\begin{array}{c}\text { Skala } \\
\text { Perbesaran } \\
\text { (Zoom) }\end{array}$ & $\begin{array}{c}\text { Penarikan } \\
\text { Batas } \\
\text { pada Sisi } \\
\text { Bidang } \\
\text { Tanah }\end{array}$ & $\begin{array}{l}\text { Easting } \\
\text { (X) }\end{array}$ & $\begin{array}{l}\text { Northing } \\
\text { (Y) }\end{array}$ & & $\begin{array}{l}\text { Easting } \\
\quad(\mathrm{X})\end{array}$ & $\begin{array}{l}\text { Northing } \\
\text { (Y) }\end{array}$ \\
\hline $1: 1000$ & Dalam & 9,6097 & 7,7959 & 1,6991 & Ditolak & Ditolak \\
\hline $1: 1000$ & Tengah & 8,5040 & 9,0148 & 1,6991 & Ditolak & Ditolak \\
\hline $1: 1000$ & Luar & 8,2506 & 6,8183 & 1,6991 & Ditolak & Ditolak \\
\hline $1: 2500$ & Dalam & - & - & - & - & - \\
\hline $1: 2500$ & Tengah & 6,6039 & 9,3326 & 1,6991 & Ditolak & Ditolak \\
\hline $1: 2500$ & Luar & - & - & - & - & - \\
\hline $1: 5000$ & Tengah & - & - & - & - & - \\
\hline
\end{tabular}


Dapat disimpulkan bahwa untuk jenis bidang tanah sawah, dari 7 percobaan yang dilakukan seluruhnya terdapat perbedaan jarak yang signifikan antara hasil delineasi fixed boundary dengan general boundary. Dan untuk jenis bidang tanah pemukiman, dari 5 percobaan yang dilakukan, seluruhnya juga terdapat perbedaan jarak yang signifikan antara hasil delineasi fixed boundary dengan general boundary.

\section{Analisis Berdasarkan Standarisasi yang telah Ditetapkan}

a. Ketelitian Luas Bidang Tanah Berdasarkan Dokumen BPN

Berdasarkan Standarisisasi Pengukuran dan Pemetaan Kadastral yang dikeluarkan oleh Bagian Proyek Administrasi Pertanahan Tahun 2003 bahwa ketelitian dari perhitungan luas (KL) bidang tanah tidak lebih besar dari $\mathrm{KL} \leq(0,5 \sqrt{\mathrm{L}}) \mathrm{m}^{2}$.

Jumlah sampel yang digunakan untuk masing-masing jenis bidang tanah adalah 10 sampel. Dari hasil analisis, didapatkan hasil sebagai berikut (Lihat Tabel 7).

Tabel 7.

Jumlah Sampel yang Memenuhi Toleransi untuk Masing- masing Jenis Bidang Tanah

\begin{tabular}{cccc}
\hline \hline \multicolumn{2}{c}{ Faktor Delineasi } & \multicolumn{2}{c}{ Jumlah Sampel yang Diterima } \\
\hline $\begin{array}{c}\text { Skala } \\
\text { Perbesaran } \\
(\text { Zoom })\end{array}$ & $\begin{array}{c}\text { Penarikan Batas } \\
\text { pada Sisi } \\
\text { Bidang Tanah }\end{array}$ & Bidang Sawah & $\begin{array}{c}\text { Bidang } \\
\text { Pemukiman }\end{array}$ \\
\hline $1: 1000$ & Dalam & 0 & 0 \\
$1: 1000$ & Tengah & 1 & 2 \\
$1: 1000$ & Luar & 2 & 1 \\
$1: 2500$ & Dalam & 2 & - \\
$1: 2500$ & Tengah & 0 & 1 \\
$1: 2500$ & Luar & 2 & - \\
$1: 5000$ & Tengah & 0 & - \\
\hline \hline
\end{tabular}

Berdasarkan Tabel 7, jumlah sampel yang paling banyak diterima untuk masing-masing jenis bidang tanah adalah hasil delineasi zooming 1:1000 pada penarikan batas sisi tengah bidang tanah, serta zooming 1:1000 pada penarikan batas sisi luar bidang tanah.

b. KetelitianLuas Bidang Tanah Berdasarkan PMNA/KBPN

Ketelitian luas bidang tanah dihitung dengan mencari selisih luas suatu bidang tanah menggunakan dua metode. Dimana salah satu metode digunakan sebagai acuan pembanding dan diasumsikan mempunyai ketelitian yang lebih baik. Berdasarkan Peraturan Menteri Negara Agraria/ Kepala Badan Pertanahan Nasional No.3 Tahun 1997 tentang Ketentuan Pelaksanaan Peraturan Pemerintah No.24 Tahun 1997 tentang Pendaftaran Tanah untuk toleransi ketelitian luas, hasil analisis yang dihasilkan dapat dilihat pada Tabel 8.

Tabel 8.

Jumlah Sampel yang Memenuhi Toleransi untuk Masing- masing Jenis Bidang Tanah

\begin{tabular}{|c|c|c|c|c|}
\hline \multicolumn{2}{|c|}{ Faktor Delineasi } & \multicolumn{2}{|c|}{$\begin{array}{c}\text { Jumlah Sampel yang } \\
\text { Diterima }\end{array}$} & \multirow[b]{2}{*}{$\begin{array}{l}\text { Toleransi } \\
\text { Ketelitian } \\
\text { Luas (\%) }\end{array}$} \\
\hline $\begin{array}{c}\text { Skala } \\
\text { Perbesaran } \\
(\text { Zoom })\end{array}$ & $\begin{array}{c}\text { Penarikan } \\
\text { Batas pada } \\
\text { Sisi Bidang } \\
\text { Tanah }\end{array}$ & $\begin{array}{l}\text { Bidang } \\
\text { Sawah }\end{array}$ & $\begin{array}{c}\text { Bidang } \\
\text { Pemukiman }\end{array}$ & \\
\hline
\end{tabular}

\begin{tabular}{ccllc}
\hline 1:1000 & Dalam & 0 & 0 & $10 \%$ \\
$1: 1000$ & Tengah & 1 & 2 & $10 \%$ \\
$1: 1000$ & Luar & 2 & 1 & $10 \%$ \\
$1: 2500$ & Dalam & 2 & - & $4 \%$ \\
$1: 2500$ & Tengah & 0 & 1 & $4 \%$ \\
$1: 2500$ & Luar & 2 & - & $4 \%$ \\
$1: 5000$ & Tengah & 0 & - & - \\
\hline \hline
\end{tabular}

Dapat dilihat pada Tabel 8 , jumlah sampel yang paling banyak diterima untuk masing-masing jenis bidang tanah adalah hasil delineasi zooming 1:1000 pada penarikan batas sisi dalam bidang tanah, serta zooming 1:1000 pada penarikan batas sisi tengah bidang tanah.

\section{c. Ketelitian Jarak Bidang Tanah Berdasarkan PMNA/KBPN}

Analisis jarak dilakukan pada titik-titik pojok sampel bidang tanah pada peta pendaftaran dan peta citra resolusi tinggi. Keduanya ditampalkan kemudian dilihat jarak yang dihasilkan oleh pergeseran titik-titik pojok bidang tanah.

Berikut adalah hasil analisis yang dilakukan berdasarkan PMNA/KBPN No.3 Tahun 1997.

Tabel 9

Jumlah Sampel yang Memenuhi Toleransi untuk Masing- masing Jenis Bidang Tanah

\begin{tabular}{|c|c|c|c|c|c|c|}
\hline \multicolumn{2}{|c|}{ Faktor Delineasi } & \multicolumn{4}{|c|}{ Jumlah Sampel yang Diterima } & \multirow{3}{*}{$\begin{array}{l}\text { Toleransi } \\
\text { Ketelitian } \\
\text { Jarak (m) }\end{array}$} \\
\hline \multirow[b]{2}{*}{$\begin{array}{c}\text { Skala } \\
\text { Perbesaran } \\
(\text { Zoom })\end{array}$} & \multirow{2}{*}{$\begin{array}{c}\text { Penarikan } \\
\text { Batas } \\
\text { pada Sisi } \\
\text { Bidang } \\
\text { Tanah }\end{array}$} & \multicolumn{2}{|c|}{ Bidang Sawah } & \multicolumn{2}{|c|}{ Bidang Pemukiman } & \\
\hline & & $\begin{array}{c}\text { Easting } \\
(\mathrm{X})\end{array}$ & $\begin{array}{l}\text { Northing } \\
\text { (Y) }\end{array}$ & $\begin{array}{c}\text { Easting } \\
\text { (X) }\end{array}$ & $\begin{array}{l}\text { Northing } \\
\text { (Y) }\end{array}$ & \\
\hline $1: 1000$ & Dalam & 0 & 2 & 2 & 5 & 0,3 \\
\hline $1: 1000$ & Tengah & 3 & 4 & 3 & 3 & 0,3 \\
\hline $1: 1000$ & Luar & 1 & 3 & 2 & 2 & 0,3 \\
\hline $1: 2500$ & Dalam & 7 & 5 & - & - & 0,75 \\
\hline $1: 2500$ & Tengah & 8 & 3 & 10 & 5 & 0,75 \\
\hline $1: 2500$ & Luar & 5 & 4 & - & - & 0,75 \\
\hline $1: 5000$ & Tengah & 6 & 12 & - & - & 1,5 \\
\hline
\end{tabular}

Seperti yang dapat dilihat pada Tabel 9, jumlah sampel yang paling banyak diterima untuk masing-masing jenis bidang tanah adalah hasil delineasi pada perbesaran skala 1:2500 untuk penarikan batas sisi tengah bidang tanah, dan pada skala perbesaran 1:5000.

\section{KESIMPULAN DAN SARAN}

Adapun beberapa hal yang bisa disimpulkan dari penelitian ini adalah:

1. Hasil analisis perbandingan delineasi metode general boundary dan metode fixed boundary menunjukkan bahwa delineasi metode general boundary pada citra satelit Quickbird tahun 2007 sebaiknya dilakukan dalam skala perbesaran (zooming) 1:1000 dengan penarikan batas bidang pada sisi tengah bidang tanah tersebut.

2. Delineasi metode general boundary pada peta citra resolusi tinggi Quickbird tahun 2007 secara keseluruhan memenuhi toleransi apabila akan digunakan dalam memenuhi kebutuhan geometrik bentuk dan luas. Akan 
tetapi apabila untuk memenuhi kebutuhan geometrik posisi, cara ini tidak bisa diterima.

Saran yang dapat diberikan dari hasil penelitian ini antara lain:

1. Alternatif lain untuk melakukan proses delineasi metode general boundary agar hasil yang didapatkan lebih maksimum adalah dengan menggunakan foto udara. Selain itu, foto udara juga dapat digunakan untuk memenuhi kebutuhan geometrik posisi.

2. Metode general boundary tidak bisa dipakai untuk kegiatan Pendaftaran Tanah. Tetapi bisa dipakai untuk kegiatan administrasi pertanahan yang lain, yaitu land value, land tenure, land use dan land development.

3. Sebaiknya setelah melakukan delineasi metode general boundary harus ditindaklanjuti dengan konsultasi ke masyarakat (pemetaan partisipatif).

\section{UCAPAN TERIMA KASIH}

Penulis A.K.W. mengucapkan terima kasih kepada Kantor Pertanahan Kabupaten Gresik yang telah memberikan dukungan berupa penyediaan data untuk penelitian.

\section{DAFTAR PUSTAKA}

[1] Anonim. 1997. Peraturan Pemerintah Nomor 24 Tahun 1997. Jakarta: Kementerian Negara Agraria.

[2] Williamson, Enemark, Wallace, Rajabifard. 2010. Land Administration for Sustainable Development. ESRI.

[3] Pantimena, Leo. 2015. Processing Orthorektifikasi dan Pengukuran Independent Check Point (ICP) Kantor Pertanahan Kabupaten Gresik. 